\title{
POTENSI PANTAI SIBOLO PULAU-PULAU BATU NIAS SELATAN UNTUK MENINGKATKAN KUNJUNGAN WISATAWAN
}

\author{
Bantors Sihombing ${ }^{1}$ ) \& Erlin Kuswindayani Bawaulu ${ }^{2}$ ) \\ bantors@akpardarmaagung.ac.id \\ Akademi Pariwisata dan Perhotelan Darma Agung
}

\begin{abstract}
ABSTRAK
Penelitian ini berjudul Potensi Wisata Pantai Sibolo Pulau-pulau Batu Kabupaten Nias Selatan untuk Meningkatkan Kunjungan Wisatawan, membahas tentang bagaimana potensi yang dimiliki pantai Sibolo untuk menarik minat kunjungan wisatawan. Metode penelitian deskriptif kualitatif. Informan penelitian ini adalah masyarakat pantai Sibolo, wisatawan, dan staff Pinnacles North Telo yang menjadi pengelola pantai Sibolo. Hasil penelitian menunjukkan pantai Sibolo memiliki potensi yang cukup untuk besar dikunjungi wisatawan namun tidak memiliki sarana dan prasarana yang lengkap seperti tourist information center, money changer, toko cenderamata atau pusat kerajinan lokal serta minimnya SDM yang terampil di bidang pariwisata. Promosi yang dilakukan belum secara maksimal dan hanya menggunakan beberapa strategi promosi saja serta belum gencarnya upaya yang dilakukan oleh pengelola objek dan daya tarik wisata pantai Sibolo dalam meningkatkan kunjungan wisatawan..
\end{abstract}

Kata Kunci: Pantai Sibolo, Pulau-pulau batu Nias Selatan, kunjungan wisatawan

\section{A.PENDAHULUAN}

Pariwisata merupakan salah satu industri terbesar dan merupakan sektor jasa dengan tingkat pertumbuhan paling pesat di dunia. Sektor pariwisata Indonesia merupakan salah satu sektor yang diharapkan dapat meningkatkan pendapatan nasional dalam upaya meningkatkan kesejahteraan dan kemakmuran rakyat, memperluas dan meratakan kesempatan lapangan kerja, memperkenalkan dan mendayagunakan objek dan potensi wisata yang terpendam, meningkatkan pendapatan masyarakat sekitar objek wisata serta merangsang aktivitas pariwisata lainnya.

Demikian halnya dengan Sumatera Utara merupakan salah satu provinsi yang memiliki potensi pariwisata yang cukup besar dan iklim tropis berupa alam, keunikan keanekaragaman budaya, daerah, peninggalan sejarah, flora dan fauna. Kabupaten Nias Selatan adalah salah satu daerah yang memiliki objek dan daya tarik wisata yang tak kalah menarik di Sumatera Utara yang memiliki keragaman objek wisata alam, budaya dan minat khusus yang dapat membangkitkan perekonomian demi tercapainya kesejahteraan masyarakat contohnya yaitu Pantai Sibolo yang terletak di Kepulauan Batu, Kabupaten Nias Selatan. Potensi yang ada di Pantai Sibolo sudah memenuhi kriteria untuk dikembangkan dan dipromosikan sebagai sebuah Daerah Tujuan Wisata karena memiliki keindahan alam, fasilitas dan dapat dikunjungi melalui jalur udara dan laut. Sebagian besar potensi ini telah dikembangkan oleh Pinnacles North Telo sebagai pengelola. Objek wisata yang ada di Pulau Sibolo ini telah dikunjungi dan diminati wisatawan 
mancanegara dan juga sebagai tempat rekreasi umum oleh masyarakat lokal, namun masih belum dikenal luas di kalangan wisatawan lainnya disebabkan oleh informasi yang minim baik melalui media sosial maupun media cetak lainnya dan perlu dikembangkan secara signifikan sehingga potensi yang ada dapat terus dikembangkan agar dapat meningkatkan minat kunjungan wisatawan.

Itu sebabnya penulis tertarik meneliti Potensi Wisata Pantai Sibolo Pulau-pulau Batu Kabupaten Nias Selatan untuk Meningkatkan Kunjungan Wisatawan

\section{B.TINJAUAN TEORITIS}

\section{Pengertian Pariwisata, dan Objek Daya Tarik Wisata}

Berdasarkan asal-usul kata, pariwisata berasal dari bahasa Sansekerta yang terdiri dari dua suku kata, yaitu kata 'pari' yang berarti dari berkeliling dan kata 'wisata' berarti perjalanan. Jadi perkataan pariwisata secara keseluruhan dapat diartikan sebagai suatu perjalanan keliling (from one place to another place), (Yoeti, 2006:111). Di dalam Kamus Besar Bahasa Indonesia, pariwisata adalah suatu kegiatan yang berhubungan dengan perjalanan rekreasi.

Menurut UU NO 10 Tahun 2009 tentang kepariwisataan, "pariwisata adalah berbagai macam kegiatan wisata dan didukung berbagai fasilitas serta layanan yang disediakan oleh masyarakat, pengusaha, pemerintah, dan pemerintah daerah".

"Pada hakekatnya pariwisata adalah suatu proses kepergian sementara dari seseorang atau lebih menuju tempat lain diluar tempat tinggalnya. Dorongan kepergian adalah karena berbagai kepentingan, baik karena kepentingan ekonomi, sosial, kebudayaan, politik, agama, kesehatan maupun kepentingan lain seperti karena sekedar ingin tahu, menambah pengalaman ataupun untuk belajar" (Suwantoro, 2004:3)

Objek wisata adalah suatu objek yang menjadi tujuan kunjungan wisatawan karena mempunyai sumber daya tarik, baik alamiah, maupun buatan manusia, seperti keindahan alam/pegunungan, pantai, fauna, flora, kebun binatang, bangunan kuno bersejarah, monumen-monumen, dan candi-candi. Menurut Direktorat Jenderal Pariwisata objek wisata adalah perwujudan ciptaan manusia, tata hidup seni budaya, serta sejarah bangsa dan tempat atau keadaan alam yang mempunyai daya tarik kunjungan wisatawan.

Menurut UU RI nomor 10 Tahun 2009 tentang Kepariwisataan bab 1 Ketentuan Umum pasal 1, ayat 5 menyatakan: "Daya Tarik Wisata adalah segala sesuatu yang memiliki keunikan, keeindahan, dan nilai yang berupa keanekaragaman kekayaan alam, budaya, dan hasil buatan manusia yang menjadi sasaran atau tujuan kunjungan wisatawan".

Suwantoro (2004 : 23 ) menjelaskan obyek wisata merupakan potensi yang menjadi pendorong kehadiran wisatawan ke suatu daerah. Selanjutnya obyek wisata ini dikelompokkan menjadi tiga golongan :

1. Obyek wisata dan daya tarik wisata alam. Obyek wisata yang daya tariknya bersumber pada keindahan dan kekayaan alam.

2. Obyek wisata dan daya tarik budaya Obyek dan daya tarik bersumber pada kebudayaan, seperti peninggalan sejarah, museum, atraksi kesenian, dan obyek lain yang berkaitan dengan budaya.

3. Obyek wisata dan daya tarik pada minat khusus 
Obyek wisata daya tariknya bersumber pada minat khusus wisatawan itu sendiri, misalnya olah raga, memancing dan lain-lain.

\section{Pengertian Potensi Pariwisata dan Wisatawan}

Potensi pariwisata adalah segala bentuk kekayaan alam, budaya sosial dan atraksi yang dapat digali dan dikembangkan untuk dijadikan menjadi suatu produk wisata.

Berikut pengertian potensi pariwisata menurut beberapa. ahli. Menurut Nyoman S. Pendit (2006: 108), potensi pariwisata merupakan segala hal dan keadaan yang diatur dan disediakan sehingga dapat dimanfaatkan sebagai kemampuan, faktor, dan unsur yang diperlukan dalam usaha dan pengembangan pariwisata baik berupa suasana, kejadian, benda, maupun jasa.

"Potensi wisata adalah sumberdaya alam yang beraneka ragam, dari aspek fisik dan hayati, serta kekayaan budaya manusia yang dapat dikembangkan untuk pariwisata. Sumberdaya wisata dapat diartikan sebagai unsur-unsur lingkungan alam atau yang telah diubah oleh manusia yang dapat memenuhi keinginan wisatawan" (Chafid Fandeli, 2001: 48-67).

"Kata wisatawan (tourist) merujuk kepada orang. Secara umum wisatawan menjadi subset atau bagian dari traveller atau visitor. Untuk dapat disebut sebagai wisatawan, seseorang haruslah seorang traveller atau seorang visitor. Seorang visitor adalah seorang traveller, tetapi tidak semua traveller adalah tourist" (Pitana \& Surya Diarta, 2009:35).

IUTO (The International Union Of Official Travel Organization) menggunakan batasan mengenai wisatawan secara umum. Pengunjung (visitor), yaitu setiap orang yang datang ke suatu negara atau tempat tinggal lain dan biasanya dengan maksud apapun kecuali melakukan pekerjaan yang menerima upah. Jadi ada dua kategori mengenai sebutan pengunjung, yakni:

a. Wisatawan (tourist)

Wisatawan adalah pengunjung yang tinggal sementara sekurangkurangnya 24 jam di suatu negara. Wisatawan dengan maksud perjalanan wisata dapat digolongkan menjadi :

1. Pesiar (leasure), untuk keperluan rekreasi, liburan, kesehatan, studi, keagamaan, dan olahraga.

2. Hubungan dagang, sanak saudara, handai taulan, konferensi, misi, dan sebagainya.

b. Pelancong (excursionist) adalah pengunjung sementara yang tinggal disuatu negara yang dikunjungi dalam waktu kurang dari 24 jam.

\section{Syarat Pengembangan Destinasi Wisata}

Selanjutnya menurut Pitana (2009) berhasil tidaknya suatu DTW adalah sangat tergantung pada faktor-faktor berikut :

1. Attractions, yakni adanya daya tarik untuk dikunjungi oleh wisatawan yang terdiri dari dua atraksi yaitu :

a. Site attraction yaitu, daya tarik yang telah dimiliki oleh alam sendiri misalnya pemandangan alam yang indah, iklim yang baik, gua-gua yang sangat menarik, panorama alam, tempat bersejarah dan sebagainya. 
b. Event attraction yaitu, daya tarik yang timbul karena adanya kejadian atau peristiwa tertentu misalnya adanya festival-festival kesenian, peristiwa olahraga dan sebagainya.

2. Accessibility, yaitu kemudahankemudahan untuk mencapai tujuan wisata atau daerah wisata dari tempat asal atau perjalanan wisata misalnya alat angkutan transportasi, kondisi jalan raya dan sebagainya.

3. Amenities, yaitu tersedianya fasilitas pada objek wisata tersebut seperti akomodasi, restoran, bar, dan fasilitas pariwisata lainnya yang dapat memenuhi kebutuhan wisatawan.

4. Tourism Organization, yakni adanya suatu organisasi pariwisata yang mengelola objek wisata dan perjalanan wisata, seperti travel agent dan lainlain.

Keberhasilan dari pada pembangunan dan pengembangan daerah tujuan wisata tersebut adalah tergantung dari faktor attraction, accessibility, amenities, dan tourism organization. Disamping itu dalam pengembangan suatu daerah tujuan wisata harus juga diperhatikan persyaratan berikut ini:

1. Something to see adalah objek wisata tersebut harus mempunyai sesuatu yang bisa di lihat atau di jadikan tontonan oleh pengunjung wisata.

2. Something to do adalah agar wisatawan yang melakukan perjalanan wisata bisa melakukan sesuatu yang berguna untuk memberikan perasaan senang, bahagia dan relax.
3. Something to buy adalah fasilitas untuk wisatawan berbelanja yang pada umumnya adalah ciri khas atau icon dari daerah tersebut, sehingga bisa di jadikan sebagi oleholeh.(Yoeti, 1985).

Ketiga macam hal di atas adalah dimaksudkan untuk menarik wisatawan mancanegara dan wisatawan nusantara yang cukup potensial atau dengan kata lain agar daerah tujuan wisata tersebut bisa menerobos pasar-pasar pariwisata.

\section{Pengertian Promosi dan Strategi Promosi}

Promosi merupakan salah satu bagian dari pemasaran, sebab tanpa adanya promosi maka perusahaan tidak akan berjalan dengan baik. Berbagai pengertian tentang promosi telah diberikan oleh para ahli dan masyarakat.

Namun secara garis besarnya promosi merupakan kegiatan/alat yang menghubungkan dengan usaha untuk memperkenalkan produknya kepada msayarakat dan sekaligus untuk meningkatkan volume penjualan atas barang dan jasa yang ditawarkan.

Menurut Philip Kotler (2000:119), promosi adalah bagian dan proses strategi pemasaran sebagai cara untuk berkomunikasi dengan pasar, dengan menggunakan komposisi bauran promosi (promotional mix)". Dewasa ini, kegiatan promosi menjadi suatu keharusan bagi suatu perusahaan, sebab pada kenyataannya betapapun besarnya manfaat suatu produk bagi konsumen namun pemasaran produk itu akan tersendat-sendat tanpa dibantu dengan promosi.

Sedangkan menurut Asri (2003:360) terdapat tiga tujuan promosi, yaitu:

1. Menginformasikan (informing), yaitu memberitahukan informasi selengkaplengkapnya kepada calon pembeli 
tentang barang yang ditawarkan, siapa penjualnya, siapa pembuatnya, dimana memperolehnya, harganya dan sebagainya. Informasi yang digunakan dapat diberikan melalui tulisan. Gambar, kata-kata dan sebagainya, yang disesuaikan dengan keadaan.

2. Membujuk (persuading), yaitu membujuk calon konsumen agar mau membeli barang atau jasa yang ditawarkan. Perlu ditekankan di sini bahwasannya membujuk bukan berarti memaksa calon konsumen sehingga keputusan yang diambil mungkin justru keputusan yang negatif.

3. Mengingatkan (reminding), yaitu mengingatkan konsumen tentang adanya barang tertentu, yang dibuat dan dijual perusahaan tertentu, ditempat tertentu dengan harga yang tertentu pula. Konsumen kadangkadang memang perlu diingatkan, karena mereka tidak ingin bersusah payah untuk selalu mencari barang apa yang dibutuhkan dan dimana mendapatkannya

Setelah perusahaan mengetahui sasaran pasarnya, maka langkah selanjutnya adalah untuk memenuhi kebutuhan dan keinginan konsumen atau pasar. Hal ini dilakukan agar terdapat kesinambungan produksi dan penjualan dan sekaligus menjamin kelangsungan hidup perusahaan. Promosi sangat penting bagi perusahaan karena tanpa promosi perusahaan tidak akan berhasil mencapai tujuannya dengan baik.

Menurut William J. Stanton yang dikutip Basu Swastha dan Irawan (2008:349) dalam bukunya Manajemen Pemasaran Modern mendefinisikan promotion mix adalah kombinasi strategi yang paling baik dari variabel-variabel periklanan, personal selling, dan alat promosi yang semuanya direncanakan untuk mencapai tujuan program penjualan. Penggunaan media promosi yang digunakan secara berlebihan atau kekurangan akan menyebabkan terjadinya penyimpangan dari apa yang diharapkan oleh perusahaan.

Adapun empat macam alat promotion mix yang dapat digunakan dalam menjalankan promosi ini yakni :

\section{Periklanan (advertising)}

Periklanan merupakan media yang sangat tepat untuk memperkenalkan produk baru atau agar produk kita tetap berkenan di hati konsumen. Tujuan periklanan terletak pada keputusan media massa yang akan digunakan, karena tiap-tiap media memiliki kesanggupan yang berbeda dalam mencapai konsumen. Adapun media periklanan yang dapat digunakan antara lain : surat kabar, majalah, televisi, radio, film, kalender dan lain-lain. Setelah media iklan ditentukan dengan pertimbangan untuk mengadakan pembelian terhadap barang dan jasa yang ditawarkan maka sebuah iklan akan memenuhi fungsinya sebagai alat promosi bila memenuhi hal-hal sebagai berikut :
a. Iklan harus menarik objek sasaran
b. Iklan harus dapat membangkitkan minat pembeli
c. Iklan harus mampu menimbulkan keinginan para pembeli
d. Iklan minimal mampu mendorong para pembeli, untuk berbuat sesuatu yang positif terhadap barang atau jasa yang ditawarkan.

Adapun keuntungan dari penggunaan media ini adalah:

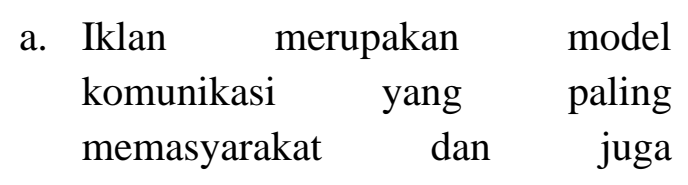




\begin{tabular}{|l|l|l|l|l}
\hline Jurnal Akomodasi Agung & Vol -VII & NO.2 & Oktober 2020 & ISSN 2503-2119 \\
\hline
\end{tabular}

memberikan penawaran yang menyebabkan terhambatnya penjualan standar. perusahaan.

b. Iklan merupakan media yang mempunyai daya serap yang paling besar sebab penjual bisa mengulang pesan mereka untuk diketahui oleh masyarakat.

c. Iklan menunjukan suatu yang positif mengenai besarnya suatu perusahaan, popularitasnya dan keberhasilannya.

d. Iklan mampu mendramatis suatu perusahaan beserta produknya melalui lukisan yang indah dan warna sehingga terkadang alat ini berhasil mengungkapkan perasaan dari konsumen atau masyarakat.

Selain keuntungan dari media periklanan ini juga terdapat kelemahan-kelemahannya yaitu iklan merupakan media promosi yang menggunakan biaya yang paling besar dalam melaksanakannya.

2. Penjualan pribadi (personal selling)

Personal selling merupakan kontak personal langsung dengan satu orang atau lebih calon pembeli dengan tujuan meningkatkan penjualan. Perbedaan personal selling dengan media promosi lainnya adalah pada komunikasi antara individu yang dilakukan personal selling sedangkan periklanan lebih bersifat komunikasi untuk massa. Penjual dapat mengetahui secara langsung apa yang dibutuhkan.

Adapun keuntungan dari media personal selling adalah sebagai berikut :
a. Berhadapan langsung secara pribadi
b. Keakraban
c. Tanggapan

Sedangkan kelemahannya adalah harus menguasai produk yang dipasarkan, apabila tidak menguasai produk yang dijual akan

\section{Promosi penjualan (sales promotion)}

Upaya meningkatkan penjualan perusahaan selain menggunakan media periklanan dapat juga melalui promosi penjualan. Kegiatan sales promotion bersifat langsung kepada konsumennya, dengan melakukan peragaan, pameran atau demonstrasi. Cara-cara ini menarik konsumen untuk mengetahui produk yang ditawarkan dan menghilangkan keraguan terhadap produk yang di promosikan. Kegiatan promosi penjualan dapat menggunakan hadiah, pameran, perlombaan, brosur, potongan harga, pelayanan setelah penjualan, dan lain-lain.

Keunggulan promosi penjualan :

a. Promosi penjualan menghasilkan respon yang lebih cepat dibandingkan dengan periklanan.

b. Penggunaan promosi penjualan untuk mendapatkan tanggapan yang lebih kuat dan lebih cepat.

Kelemahan promosi penjualan adalah kurangnya pertimbangan mengenai efektivitas biaya.

\section{Publisitas (publicity)}

Publitas adalah berita atau informasi tentang produk tertentu yang di publikasikan, tanpa imbalan atau bersifat bebas biaya. Publisitas adalah penempatan berupa artikel, tulisan, foto atau tayangan visual yang sarat nilai berita baik karena luar biasa, penting, atau mengandung, unsur - unsur emosiaonal, kemanusiaan dan humor secara gratis dan bertujuan untuk memusatkan perhatian terhadap suatu tempat, orang, atau suatu institusi yang biasanya dilakukan melalui penerbitan umum. Contoh lain yaitu memuat berita-berita yang sifatnya komersil di dalam media yang dipublikasikan atau penyajiannya secara tepat melalui televisi, radio, atau 
bioskop-bioskop dan seluruhnya ini tidak dibayar oleh sponsor.

\section{METODE PENELITIAN}

Penelitian ini menggunakan pendekatan kualitatif yaitu suatu proses penelitian dan pemahaman yang berdasarkan pada metodologi yang menyelidiki suatu fenomena sosial dan masalah manusia (Utama, 2012:119). Bogdan dan Taylor (Moleong, 2010) mengemukakan bahwa metodologi kualitatif merupakan prosedur penelitian yang menghasilkan data deskriptif berupa kata-kata tertulis maupun lisan dari orangorang dan perilaku yang diamati. Metode penelitian ini adalah studi kasus (Kriyantono, 2014:65) yang mengeksplorasi suatu masalah dengan batasan terperinci, memiliki pengambilan data yang mendalam dan menyertakan berbagai sumber informasi. Kasus yang dipelajari berupa program, peristiwa, aktivitas atau individu.Penelitian ini dilaksanakan di Pantai Sibolo, Kabupaten Nias Selatan. Waktu penelitian diadakan pada bulan Juli 2020. Adapun Objek penelitian ini adalah

Informan penelitian ini adalah masyarakat pantai Sibolo, wisatawan, dan staff Pinnacles North Telo yang menjadi pengelola pantai Sibolo. Teknik pengambilan sampel berdasarkan purposive sampling untuk unsur masyarakat dan wisatawan. Sedangkan instrumen penelitian adalah peneliti sendiri.Teknik pengumpulan data dilakukan tanpa angket. Pengumpulan data dilakukan dengan observasi dan wawancara serta studi pustaka. Selain itu melakukan juga wawancara terbuka walaupun tidak terstruktur (Ardial, 2014 : 257). Analisis data dilakukan dengan menyusun data, dan memadukannya dalam suatu golongan, pola dan satuan dasar. Lalu menjelaskan pola uraian dan menghubungkan temuan-temuan dalam penerlitian.Analisis data dilakukan sejak pengumpulan data sampai sesudah meninggalkan lapangan (Utama, 2012:143144).

\section{HASIL DAN PEMBAHASAN}

\section{Potensi Objek dan Daya Tarik Wisata Pantai Sibolo, Pulau-Pulau Batu Kabupaten Nias Selatan.}

Potensi adalah segala bentuk dan kekayaan alam, budaya, sosial dan atraksi yang dapat digali dan dikembangkan untuk dijadikan menjadi suatu produk wisata. Potensi yang tercipta akan lebih besar apabila didukung dengan sarana dan prasarana serta fasilitas yang memadai. Objek dan daya tarik wisata pantai Sibolo mempunyai potensi yang cukup besar dan mempunyai prospek yang baik dimasa yang akan datang apabila terus dibangun dan dikembangkan dan akan menjadi objek wisata yang populer. Pemandangan pantai yang indah dan eksotik, udara yang sejuk dan segar serta penduduk yang ramah menjadi alasan utama kenapa objek wisata ini layak untuk dikembangkan.

Selain beberapa alasan di atas, tujuan wisatawan berkunjung juga untuk surfing, diving, fishing atau sekedar menikmati hamparan pasir putih dan air laut yang jernih. penyewaan boat untuk keliling pulau atau menuju spot wisata lain. Untuk pecinta wisata bahari, aktivitas wisata seperti swimming dengan lautan hijau biru yang seumpama akuarium alam akan memanjakan liburan. Fishing mania bersama nelayan lokal, surfing dengan gulungan ombak terbaik bagi para surfer pemula maupun profesional. Snorkelling dan diving menikmati keindahan 
bawah laut dan hamparan terumbu karang yang masih terjaga. Tour around island, mengelilingi pulau yang dikelilingi pasir putih lembut. Fotografi dengan nuansa alam laut dan pantai, dan fotografi bawah laut. Menikmati sunset dan sunrise. Berjemur diatas pasir lembut, menikmati waktu santai dan hembusan angin di wilayah yang tenang, bebas polusi serta nyaman dan ramah untuk pengunjungnya.

\section{Promosi Wisata Pantai Sibolo Yang Belum Dilakukan Secara Maksimal.}

Promosi merupakan aspek paling penting dalam pengembangan objek wisata dan menjaga kelangsungan objek wisata tetap dikunjungi oleh wisatawan. Adapun alat promotion mix yang sudah di terapkan untuk mempromosikan pantai Sibolo yakni :

1. Periklanan (advertising)

Adapun media periklanan yang digunakan yaitu papan reklame/poster yang dipasang di bandara dan pelabuhan.

2. Penjualan pribadi (Personal selling) yaitu meningkatkan penjualan dengan melakukan kontak langsung dengan satu orang atau lebih calon pembeli.

3. Promosi penjualan dengan menggunakan brosur

4. Publisitas dengan menggunakan media sosial seperti :
a. Website : www.Pegasuslodge.com
b. Facebook : Pinnacles North Telo
c. Instagram :
@ pinnaclestelo

Informan mengatakan strategi promosi yang digunakan oleh pengelola ODTW pantai Sibolo masih sangat sedikit misalnya melalui media iklan yang hanya menggunakan papan reklame dan tidak menggunakan media iklan lainnya seperti surat kabar, televisi, radio, dan lain-lain. Promosi penjualan yang hanya menggunakan media brosur dan tidak menggunakan media lain seperti pameran, promo potongan harga, dan lain-lain.

\section{Upaya Yang Dilakukan Oleh Pengelola Objek Dan Daya Tarik Wisata Pantai Sibolo Dalam Meningkatkan Minat Wisatawan.}

Upaya merupakan kegiatan atau usaha yang dilakukan oleh seseorang atau kelompok untuk mencapai sebuah maksud dan tujuan tertentu. Pihak pengelola pantai Sibolo juga telah melakukan beberapa upaya dalam mencapai tujuan untuk meningkatkan minat kunjungan wisatawan

Upaya yang sudah dilakukan yaitu :

1. Membuat website resmi yaitu www.pegasuslodge.com dimana didalamnya terdapat produk wisata , jadwal wisata, waktu dan lokasi serta alamat perusahaan , fax, email, nomor telpon dan contact person.

2. Melakukan promosi produk pariwisata lewat jejaring seperti: facebook dan instagram.

3. Menggunakan media konvesional seperti membuat brosur yang menarik dan informatif dengan kertas dan gambar yang berkualitas

4. Memberikan guestbag dan form penilaian kepada tamu saat hari terakhir berwisata. Apabila penilaian wisatawan puas maka dianjurkan untuk menceritakan kepada kerabat atau keluarga agar berkunjung kembali. 
Informan menilai upaya pengelola ODTW pantai Sibolo belum cukup untuk meningkatkan minat kunjungan wisatawan ke pantai Sibolo. Masih banyak upaya yang belum dilakukan seperti : mengadakan even pariwisata, menjadi sponsor di acara bertema pariwisata, bekerjasama dengan pemerintah dalam memajukan pariwisata pantai Sibolo, bergabung dalam komunitas pariwisata dan lain sebagainya.

\section{E. KESIMPULAN DAN SARAN}

\section{Kesimpulan}

a. Pantai Sibolo adalah salah satu objek yang berpotensi cukup besar apabila ditinjau dari hasil penelitian ke objek tersebut dimana alamnya sangat sejuk dan masih alami, pantai pasir putih yang membentang luas dan dengan pesona lautan hijau biru yang mendukung pengembangannya untuk dapat menarik jumlah kunjungan wisatawan. Untuk pecinta wisata bahari, aktivitas wisata seperti swimming, fishing mania, surfing, Snorkelling dan diving dapat dilakukan di ODTW ini. Agar dapat dikunjungi wisatawan perlu dilakukan pembangunan sarana dan prasarana seperti tourist information center, money changer, toko cenderamata dan pusat kerajinan tangan lokal serta memperkerjakan SDM yang terampil atau profesional dalam bidang pariwisata. Hal ini menjadi pendukung agar mempermudah wisatawan dalam melakukan perjalanan wisata ke pantai Sibolo, Pulau-Pulau Batu Kabupaten Nias Selatan

b.Kegiatan promosi dilakukan dengan tujuan supaya pantai Sibolo dapat dikenal lebih luas di kalangan masyarakat atau wisatawan lainnya. Promosi yang dilakukan oleh Pinnacles North Tello di pantai Sibolo belum diterapkan secara maksimal, dengan hanya menggunakan media papan reklame/poster, brosur serta publisitas melalui media sosial belum cukup untuk memperkenalkan wisata pantai Sibolo di kalangan masyarakat atau wisatawan lain. Untuk itu agar dapat dikenal lebih luas perlu menggunakan strategi promosi seperti media surat kabar, majalah, televisi, radio, film, kalender, pameran, peragaan, hadiah, dan potongan harga agar tujuan untuk meningkatkan minat kunjungan wisatawan ke pantai Sibolo, Pulau-Pulau Batu Kabupaten Nias Selatan dapat tercapai dan terlaksana dengan baik.

c. Dalam mencapai tujuan untuk meningkatkan minat kunjungan wisatawan ke pantai Sibolo pengelola telah melakukan beberapa upaya seperti membuat website resmi yang berisi semua informasi tentang paket wisata ke pantai Sibolo, melakukan promosi melalui akun media sosial seperti facebook dan instagram, membuat brosur yang menarik dan informatif serta memberikan guest bag kepada tamu. Namun upaya yang dilakukan tersebut belum cukup untuk meningkatkan minat kunjungan wisatawan ke pantai Sibolo, Pulau-Pulau Batu Kabupaten Nias Selatan. Beberapa upaya lain yang dapat dilakukan seperti mengadakan even pariwisata, Menambah atraksi baru, menjadi sponsor di acara bertema pariwisata, bekerjasama dengan pemerintah dalam memajukan pariwisata pantai Sibolo, bergabung dalam komunitas pariwisata dan lain sebagainya

2 Saran

a. Meningkatkan sarana dan prasarana sebagai salah satu pendukung kepariwisataan seperti tourist information center, money changer, serta pusat perbelanjaan souvenir atau kerajinan tangan masyarakat lokal serta 
memperkerjakan SDM yang terampil atau profesional dalam bidang pariwisata.

b.Melakukan promosi menggunakan media periklanan seperti surat kabar, majalah, televisi, radio, film, kalender serta melakukan promosi penjualan seperti pameran, peragaan, hadiah, dan potongan harga.

c. Mengadakan even pariwisata, menambah atraksi baru dan menjadi sponsor di acara bertema pariwisata.

d. Bekerjasama dengan pemerintah dan travel agent milik swasta.

\section{DAFTAR PUSTAKA}

Ardial, H. (2014). Paradigma dan Model Penelitian Komunikasi, Jakarta : PT Bumi Aksara Asri, Marwan, (2003), Marketing. Jakarta: Penerbit Erlangga

Basu Swasta, Dharmesta dan Irawan, (2008), Manajemen Pemasaran Modern, Yogyakarta : Liberty

Badan Pengembangan dan Pembinaan Bahasa.(2016). Kamus Besar Bahasa Indonesia, Jakarta: Kemendikbud,

Kriyantono, Rachmat.(2014). Teknik Praktis

Riset Komunikasi, Jakarta : Kencana Prenadamedia Group

Kotler, Philip, (2000), Prinsip - Prinsip Pemasaran Manajemen, Jakarta : Prenhalindo.

M. A, Morissan, (2012), Metode Penelitian Survei, Jakarta : Kencana.

Moleong, (2010), Metodologi Penelitian Kualitatif, Bandung : Remaja Rosda Karya

Pendit, S. Nyoman, (2006), Ilmu Parwisata : Sebuah Pengantar, Jakarta : PT. Pradnya Paramita

Pitana,. I Gde \& Surya Diarta, I Ketut, (2009), Pengantar Ilmu Pariwisata, Yogyakarta : Andi
Suwantoro, Gamal, (2004), Dasar-dasar Pariwisata, Yogyakarta: Andi

Utama. I Gusti Bagus Rai. (2012). Metodologi Penelitian Pariwisata dan Perhotelan, Yogyakarta :CV Andi Offset

UU No 10 Tahun (2009) Tentang Kepariwisataan

Yoeti, Oka A, (2006), Pengantar Ilmu Pariwisata, Bandung : Surya Angkasa 